\title{
Problematik Interpretasi Pengaturan Kepailitan Terhadap Jabatan Notaris di Indonesia
}

\author{
Amanda Maylaksita \\ Magister Kenotariatan Universitas Islam Indonesia Yogyakarta \\ Jln. Cik Di Tiro No. 1 Yogyakarta \\ maylaksitaa@yahoo.com
}

\begin{abstract}
Bankruptcy regulation according to Article 12 point a of Law No. 2 of 2014 on Notary Positions lead to different interpretations and this article provide sanctions to Notaries by dismissing them disrespectfully if the Notaries has been declared bankrupt by a court decision. This disrespectful dismissal is a treatment that is not in accordance with the concept of bankruptcy that has been regulated in Law No. 37 of 2004 on Bankruptcy. This study aims to determine and analyze bankruptcy regulation for Notaries based on Law No. 2 of 2014 on Notary Positions and Law No. 37 of 2004 on Bankruptcy as well as the legal consequences of Notaries declared bankrupt. This is a type of normative legal research using the legislation and conceptual approach and analyze it using descriptive qualitative methods. This research uses primary and secondary legal materials. The results of this study conclude that the regulation of bankruptcy of a Notary Public based on Article 12 point a of the Notary Law is not to cause disrespectful dismissal from his position. Notary as a legal subject that represents an individual who has a debt. The legal consequences of a bankrupt notary based on the Bankruptcy Law only causes a person to lose the right to act freely on his assets but not lose the right to carry out his profession and position. Suggestions from this research are, the government needs to do a review in order to amend the regulation on bankruptcy for the Notary to avoid mis-interpretations.
\end{abstract}

Keyword: Bankruptcy; legal consequence; notary; regulation

\begin{abstract}
Abstrak
Pengaturan Kepailitan menurut Pasal 12 huruf a Undang-Undang Nomor 2 Tahun 2014 tentang Jabatan Notaris menyebabkan penafsiran yang berbeda-beda dan pasal tersebut memberikan sanksi kepada Notaris dengan memberhentikan secara tidak hormat apabila Notaris telah dinyatakan pailit oleh putusan pengadilan. Pemberhentian secara tidak hormat ini merupakan perlakuan yang tidak sesuai dengan konsep kepailitan yang telah diatur dalam Undang-Undang Nomor 37 Tahun 2004 tentang Kepailitan. Penelitian ini bertujuan untuk mengetahui dan menganalisis pengaturan kepailitan terhadap Notaris berdasarkan Undang-Undang Nomor 2 Tahun 2014 tentang Jabatan Notaris dan Undang-Undang Nomor 37 Tahun 2004 tentang Kepailitan serta akibat hukum terhadap Notaris yang dinyatakan pailit. Jenis penelitian yang digunakan adalah jenis penelitian hukum normatif dengan menggunakan pendekatan perundang-undangan dan pendekatan konseptual serta menganalisisnya dengan menggunakan metode deskriptif kualitatif. Penelitian ini menggunakan bahan hukum primer dan bahan hukum sekunder. Hasil penelitian ini menyimpulkan bahwa pengaturan kepailitan Notaris berdasarkan Pasal 12 huruf a Undang-Undang Jabatan Notaris adalah tidak menyebabkan dapat diberhentikan secara tidak hormat dari jabatannya. Notaris sebagai subjek hukum yang mewakili orang perorangan yang mempunyai utang. Akibat hukum dari notaris pailit berdasarkan Undang-Undang Kepailitan hanya menyebabkan seorang kehilangan hak untuk berbuat bebas terhadap harta kekayaannya saja tetapi tidak kehilangan hak untuk menjalankan profesi dan jabatannya. Saran dari penelitian ini, yakni pemerintah perlu melakukan kajian ulang guna merevisi regulasi tentang kepailitan bagi Notaris agar tidak terjadi banyak penafsiran.
\end{abstract}

Kata-kata Kunci : Pengaturan; kepailitan; notaris; akibat hukum 


\section{Pendahuluan}

Kepailitan merupakan suatu kondisi ketika seorang debitur yang mempunyai kesulitan keuangan untuk membayar utangnya dinyatakan pailit oleh pengadilan, dalam hal ini Pengadilan Niaga, dikarenakan debitur tidak dapat membayar utangnya sampai batas jatuh tempo ditentukan. Kepailitan dalam sejarahnya di tahun 1934 hanya dapat diperuntukkan bagi pedagang, namun seiring perubahan zaman dan perkembangan di bidang ekonomi, kepailitan tidak hanya dialami oleh pedagang tetapi juga terhadap pihak yang memiliki utang dan dalam keadaan insolvensi.

Mekanisme hukum kepailitan, konsep utang sangat menentukan, karena tanpa adanya utang, kepailitan kehilangan esensinya sebagai pranata hukum untuk melikuidasi harta kekayaan debitur guna membayar utang-utangnya kepada para krediturnya. ${ }^{1}$ Utang merupakan unsur utama yang harus dipenuhi agar dapat dimohonkan pailit selain juga terdapat syarat lain seperti adanya dua kreditur atau lebih sebagaimana diatur dalam Pasal 2 ayat (1) Undang-Undang Nomor 37 Tahun 2004 tentang Kepailitan dan Penundaan Kewajiban Pembayaran Utang (Undang-Undang Kepailitan). Undang-Undang Kepailitan mengatur bahwa yang dapat dimohonkan pailit tidak hanya badan hukum seperti Perseroan Terbatas, tetapi juga orang perorangan sebagaimana dimaksud dalam Pasal 1 angka 11 Undang-Undang Kepailitan.

Salah satu akibat hukum dari kepailitan adalah mulai saat itu debitur kehilangan hak atau kewenangannya untuk mengurus (daden van behoreen) dan melakukan perbuatan kepemilikan (daden van beschikking) terhadap harta kekayaannya yang termasuk dalam kepailitan. Hal ini disebutkan dalam Pasal 24 ayat (1) Undang-Undang Kepailitan bahwa debitur demi hukum kehilangan haknya untuk menguasai dan mengurus kekayaannya yang termasuk dalam harta pailit sejak tanggal putusan pernyataan pailit diucapkan.

1 M. Hadi Shubhan, Hukum Kepailitan, Prinsip, Norma, dan Praktik di Peradilan, Kencana Prenada Media Group, Jakarta, 2008, hlm. 34 
Notaris adalah pejabat umum yang berwenang untuk membuat akta otentik dan kewenangan lainnya yang diatur di dalam Pasal 1 angka 1 Undang-Undang Nomor 2 Tahun 2014 tentang Jabatan Notaris (Undang-undang Jabatan Notaris). Pembuatan akta otentik, ada yang diharuskan oleh peraturan perundangundangan, dalam rangka menciptakan kepastian, ketertiban, dan perlindungan hukum, namun bisa juga dibuat oleh atau dihadapan Notaris. Hal ini bukan saja karena diharuskan oleh peraturan perundang-undangan, tetapi juga karena dikehendaki oleh pihak-pihak yang berkepentingan, untuk memastikan hak dan kewajiban para pihak terlindungi secara hukum.

Notaris adalah seseorang yang keterangan-keterangannya dapat diandalkan, dapat dipercaya, yang tandatangannya serta segelnya (capnya) memberi jaminan dan bukti yang kuat. Notrais merupakan seorang ahli yang tidak memihak dan penasihat yang tidak ada cacatnya (onkreukbaar atau unimpeachable), yang tutup mulut dan membuat suatu perjanjian yang dapat melindungi di hari-hari yang akan datang. Apabila seorang Advokat membela hak seseorang ketika timbul suatu kesulitan, maka seorang Notaris harus berusaha mencegah terjadinya kesulitan itu. $^{2}$

Berdasarkan kewenangan Notaris tersebut, maka akta Notaris mempunyai kekuatan pembuktian yang sempurna sehingga dapat menjamin kepastian, ketertiban dan perlindungan hukum bagi pihak-pihak yang berinsikan kebenaran dan keadilan bagi mereka. Wewenang Notaris tersebut merupakan wewenang yang ditentukan berdasarkan peraturan perundang-undangan yang dibentuk oleh lembaga negara (Pemerintah bersama-sama Dewan Perwakilan Rakyat) atau Pejabat Negara yang berwenang dan mengikat secara umum. ${ }^{3}$

Profesi Notaris termasuk ke dalam jenis profesi yang dinamakan profesi luhur seperti yang dimaksud oleh C.S.T Kansil dan Christine S.T Kansil, yaitu suatu profesi yang pada hakikatnya merupakan suatu pelayanan pada masyarakat. Orang yang menjalankan profesi luhur tersebut juga memeroleh nafkah dari pekerjaannya, tetapi hal tersebut bukanlah motivasi utamanya. Adapun yang

2 Tan Thong Kie, Studi Notariat beberapa mata pelajaran dan Serba Serbi praktek Notaris, PT. Ichtiar Baru Van Hoeve, Jakarta, 1994, hlm. 224.

${ }_{3}^{3}$ Rosjidi Ranggawidjaya, Pengantar Ilmu Perundang-Undangan Indonesia, Mandar Maju, Bandung, 1998, hlm. 19. 
menjadi motivasi utamanya adalah kesediaan yang bersangkutan untuk melayani sesamanya. 4

Undang-Undang Jabatan Notaris mengatur tentang sanksi terhadap Notaris pailit sebagaimana diatur dalam Pasal 9 ayat (1) huruf a dan Pasal 12 huruf a Undang-undang Jabatan Notaris. Pasal 9 ayat (1) huruf a Undang-Undang Jabatan Notaris mengatur bahwa, Notaris diberhentikan sementara dari jabatannya karena dalam proses pailit atau penundaan kewajiban pembayaran utang, berada dibawah pengampuan, melakukan perbuatan tercela atau melakukan pelanggaran terhadap kewajiban dan larangan jabatan. Sedangkan Pasal 12 huruf a Undang-Undang Jabatan Notaris mengatur bahwa, Notaris diberhentikan secara tidak hormat dari jabatannya oleh Menteri atas usul Majelis Pengawas Pusat apabila dinyatakan pailit berdasarkan putusan pengadilan yang telah memperoleh kekuatan hukum tetap, berada dibawah pengampauan secara terus menerus lebih dari 3 (tiga) tahun, melakukan perbuatan yang merendahkan kehormatan dan martabat jabatan Notaris dan melakukan pelanggaran berat terhadap kewajiban dan larangan jabatan.

Alasan pemberhentian Notaris secara tidak hormat akibat keadaan pailit yang telah diputuskan oleh Pengadilan dianggap oleh banyak kalangan sebagai suatu alasan yang kurang tepat dan tidak dapat diterapkan pada jabatan Notaris. Jika melihat bunyi Pasal 12 huruf a Undang-Undang Jabatan Notaris terdapat ketidakjelasan makna dari pasal tersebut. Tidak ada penjelasan yang spesifik mengenai apakah yang dipailitkan tersebut Notaris dalam kapasitasnya sebagai orang pribadi (natuurlijk persoon) atau sebagai pejabat umum, dan mengenai maksud kapasitas Notaris sebagai pejabat umum. Karena dalam Undang-Undang Kepailitan dijelaskan bahwa subyek pailit hanyalah orang pribadi atau badan hukum.

Pasal 22 Undang-Undang Kepailitan mengatur pengecualian harta pailit. Pasal tersebut menyebutkan bahwa hasil yang diperoleh debitur dari pekerjaannya sendiri sebagai penggajian dari suatu jabatan tidak dapat dimasukkan kedalam objek kepailitan dan segala perlengkapan yang sehubungan dengan pekerjaannya juga tidak boleh disita. Sehingga jika di dalam Undang-Undang Jabatan Notaris, Notaris

${ }^{4}$ C.S.T. Kansil dan Christine S.T.Kansil, Pokok-Pokok Etika Profesi Hukum, Pradnya Paramita, Jakarta, 1997, 
tidak dapat menjalankan profesi jabatannya ketika telah dinyatakan pailit, maka hal ini sangat bertentangan dengan isi regulasi dari Undang-undang Kepailitan. Norma dalam Undang-undang Kepailitan sebagai lex specialis dalam kondisi kepailitan akan berbenturan dengan Pasal 12 huruf a Undang-Undang Jabatan Notaris.

Apabila ada pihak yang mengaitkan antara kepailitan dengan hal-hal lain diluar harta kekayaan debitur pailit adalah tidak tepat. Karena kepailitan bukanlah suatu vonis yang menjadikan debitur pailit tidak cakap dan tidak wenang dalam segala-galanya. Pasal 12 huruf a Undang-Undang Jabatan Notaris tidak selaras dengan ketentuan yang diatur di dalam Undang-Undang Kepailitan, karena akibat hukum kepailitan di dalam Undang-Undang Kepailitan tersebut tidaklah seperti yang diatur di dalam Undang-Undang Jabatan Notaris yang sampai dapat memberhentikan seseorang dari jabatannya.

Menurut Undang-Undang Kepailitan, debitur tetap cakap hukum dan hanya tidak berwenang untuk mengurus harta kekayaannya saja. Oleh karena itu, Notaris yang telah dinyatakan pailit masih cakap untuk menjalankan kewenangannya sebagai pejabat, namun tetap di bawah pengawasan kurator, kurator disini bertugas melakukan pengurusan dan pemberesan harta pailit milik debitur pailit. Dengan tetap menjalankan profesi jabatannya, maka Notaris dapat menambah harta pailitnya untuk membayar utang-utangnya. Tetapi menurut Undang-Undang Jabatan Notaris, Notaris yang sedang dalam proses pailit akan diberhentikan sementara dan ketika sudah dinyatakan pailit oleh putusan pengadilan maka akan diberhentikan secara tidak hormat dari jabatannya, sehingga dapat dikatakan bahwa Notaris dianggap tidak cakap dalam menjalankan kewenangannya sebagai Notaris.

Ketentuan sanksi yang diatur dalam Pasal 12 huruf a Undang-Undang Jabatan Notaris terhadap Notaris menjadi tidak sesuai dengan akibat hukum kepailitan yaitu ketidakcakapan sampai dengan harta kekayaannya saja. Adanya kekaburan dan benturan norma dalam Pasal 12 huruf a Undang-Undang Jabatan Notaris tersebut dapat menyebabkan kesalahan dalam menerapkan peraturan perundang-undangan. Undang-undang Jabatan Notaris juga tidak menentukan akibat hukumnya apabila Notaris pailit, sehingga hal tersebut menimbulkan pertanyaan terkait dengan dokumen-dokumen rahasia milik Notaris, apakah ada dalam pengawasan kurator ataukah ada perlindungan hukum lainnya. 


\section{Rumusan Masalah}

Berdasarkan urian latar belakang di atas, rumusan masalah yang hendak dikaji dalam penelitian ini adalah: pertama, bagaimana pengaturan kepailitan terhadap Notaris berdasarkan Undang-Undang Nomor 2 Tahun 2014 tentang Jabatan Notaris dan Undang-Undang Nomor 37 Tahun 2004? Kedua, bagaimana akibat hukum terhadap Notaris yang dinyatakan Pailit?

\section{Tujuan Penelitian}

Penelitian ini bertujuan untuk mengetahui dan menganalisis hal-hal yang terkait dengan kepailitan Notaris sebagaimana diatur dalam Undang-Undang Nomor 2 Tahun 2014 tentang Jabatan Notaris dan Undang-Undang Nomor 37 Tahun 2004, serta mengetahui akibat hukum terhadap Notaris yang dinyatakan Pailit.

\section{Metode Penelitian}

Penelitian ini termasuk jenis penelitian hukum normatif yang menelaah teoriteori, konsep-konsep, asas-asas hukum serta peraturan perundang-undangan yang berhubungan dengan penelitian ini. Penelitian ini menggunakan data sekunder yang terdiri atas bahan hukum primer dan bahan hukum sekunder. Bahan hukum primer yang dikaji antara lain Undang-Undang Nomor 2 Tahun 2014 tentang Jabatan Notaris dan Undang-Undang Nomor 37 Tahun 2004 tentang Kepailitan. Pendekatan penelitian yang akan digunakan adalah pendekatan perundangundangan dan pendekatan konseptual. Data yang diperoleh dari penelitian dianalisa dengan menggunakan metode deskriptif kualitatif.

\section{Hasil Penelitian dan Pembahasan}

Kepailitan terhadap Notaris berdasarkan Undang-Undang Nomor 2 Tahun 2014 tentang Jabatan Notaris dan Undang-Undang Nomor 37 Tahun 2004 tentang Kepailitan

Berdasarkan Pasal 12 huruf a Undang-Undang Nomor 2 Tahun 2014 tentang Jabatan Notaris, Notaris diberhentikan dengan tidak hormat dari jabatannya atas usul Majelis Pengawas Pusat (MPP) apabila telah dinyatakan pailit berdasarkan putusan pengadilan yang telah memperoleh kekuatan hukum tetap. Pasal 12 huruf 
a tersebut tidak memberikan penjelasan secara terperinci perihal Notaris yang telah dinyatakan pailit, apakah Notaris dipailitkan berdasarkan jabatannya atau sebagai orang pribadi. Apabila Notaris dipailitkan dalam jabatannya, Undang-Undang Jabatan Notaris juga tidak mengatur secara rinci mengenai konsekuensi hukumnya. Pasal 12 huruf a mengatur tentang Notaris diberhentikan secara tidak hormat apabila telah dinyatakan pailit oleh Pengadilan yang berkekuatan hukum tetap, maka disini banyak pertentangan yang terjadi.

Menurut penulis kepailitan yang terjadi pada debitur yang berprofesi sebagai Notaris tersebut tidak menyebabkan dapat diberhentikan secara tidak hormat dari jabatannya seperti yang telah disebutkan dalam Pasal 12 huruf a Undang-Undang Jabatan Notaris. Kepailitan bukan sebuah kriminalitas dan kepailitan merupakan hal yang manusiawi, artinya kepailitan dapat terjadi pada setiap orang. Notaris disini adalah jabatan, jadi bukan karena kapasitasnya sebagai Notaris yang dipailitkan akan tetapi sebagai debitur yang mempunyai utang. Akibat hukum bagi debitur yang berprofesi sebagai Notaris ditinjau dari Undang-Undang Kepailitan tidaklah menyebabkan Notaris tidak dapat menjalankan profesi dan jabatannya karena tidak termasuk dalam objek kepailitan.

Disini terjadi benturan norma antara Undang-Undang Jabatan Notaris dan Undang-undang Kepailitan. Meski Undang-Undang Kepailitan tidak khusus mengatur jabatan Notaris, namun konteks pengaturan pemberhentian Notaris akibat kepailitan sebagaimana diatur dalam Undang-Undang Jabatan Notaris seharusnya lebih mengacu pada Undang-Undang Kepailitan. Undang-Undang Kepailitan merupakan induk dari semua masalah kepailitan. Undang-Undang Nomor 37 Tahun 2004 tentang Kepailitan mengatur bahwa debitur pailit demi hukum hanya kehilangan haknya untuk mengurus dan melakukan perbuatan kepemilikkan terhadap harta kekayaannya yang termasuk dalam obyek kepailitan. Kehilangan hak bebasnya tersebut hanya terbatas pada harta kekayaannya dan tidak terhadap status pribadinya. Debitur yang dalam status pailit tidak akan menghilangkan hak-hak keperdataanya serta hak-hak lain selaku warga negara seperti hak politik dan hak privat lainnya. Menurut Habib Adjie bahwa yang dimaksud Notaris pailit adalah:

Jika Notaris tersebut digugat untuk memberikan ganti rugi akibat kesalahannya yang menyebabkan suatu akta menjadi kehilangan kekuatan 
pembuktian sebagai akta otentik, atau suatu akta yang dibuat oleh atau dihadapannya menjadi batal demi hukum sehingga menimbulkan kerugian bagi para pihak, dan ternyata nilai kerugian yang dituntut begitu besar, sehingga seluruh harta Notaris tersebut tidak mencukupi untuk menggantinya, dinyatakan pailit berdasarkan keputusan pengadilan yang berkekuatan hukum tetap. ${ }^{5}$

Notaris yang dinyatakan pailit menurut Pasal 12 huruf a Undang-Undang Jabatan Notaris apabila dituntut ganti rugi oleh para pihak atau penghadap, karena akta yang dibuat oleh atau di hadapan Notaris ternyata melakukan wanprestasi atau perbuatan melawan hukum. Apabila tindakan ini mengakibatkan kerugian bagi para pihak tersebut, sehingga Notaris wajib untuk membayar ganti rugi. Agar gugatan tersebut tidak sia-sia maka dapat dijatuhkan sitaan (conservatoir beslag) atas benda bergerak milik Notaris. Maka, dari hal-hal di atas yang dapat menyebabkan pailitnya seorang Notaris adalah apabila telah memenuhi unsur yang menjadi pokok dapat terjadinya kepailitan yaitu utang. Tanpa adanya utang, maka kepailitan akan kehilangan esensinya sebagai pranata hukum untuk melikuidasi harta kekayaan debitur guna membayar utang-utangnya kepada para krediturnya. ${ }^{6}$

Jika putusan pengadilan telah memeroleh kekuatan hukum tetap maka wajib bagi Notaris untuk membayar ganti rugi, bunga dan lain-lainnya kepada penggugat. Harta benda Notaris yang telah disita dapat dilelang, dan uang lelang tersebut dapat digunakan untuk membayar ganti rugi kepada penggugat. Apabila akta yang dibuat dihadapan atau oleh Notaris bermasalah karena para pihak sendiri, maka hal tersebut menjadi urusan para pihak sendiri dan Notaris tidak dapat dilibatkan, karena Notaris bukan pihak dalam akta. Apabila memang Notaris melakukan kesalahan maka para pihak wajib membuktikan hal-hal yang diingkarinya.

Akta yang dibuat Notaris adalah akta otentik yang mempunyai kekuatan pembuktian sempurna, sehingga jika ada orang atau pihak yang menilai atau menyatakan bahwa akta tersebut tidak benar, maka orang atau pihak tersebut

${ }^{5}$ Habib Adjie, Sanksi Perdata dan Administrasi Terbadap Notaris Sebagai Pejabat Publik. Refika Aditama, Bandung, 2008, hlm. 64

${ }^{6}$ M. Hadi Shubhan, Hukum Kepailitan, Prinsip..., Op. Cit., hlm. 34. 
wajib membuktikan penilaian atau pernyataannya sesuai aturan hukum. Jika gugatan terhadap pengikaran tersebut tidak terbukti, maka akta Notaris tersebut tetap berlaku dan mengikat para pihak dan pihak-pihak yang terkait sepanjang tidak dibatalkan oleh para pihak sendiri atau berdasarkan putusan pengadilan. Namun, apabila gugatan tersebut terbukti, maka akta Notaris terdegradasi kedudukannya dari akta otentik menjadi akta dibawah tangan. Sebagai akta dibawah tangan maka nilai pembuktiannya tergantung para pihak dan hakim yang menilainya. Jika pedegradasian kedudukan akta tersebut ternyata merugikan pihak yang bersangkutan dan dapat dibuktikan oleh pengugat, maka penggugat dapat menuntut ganti rugi kepada Notaris. Perbuatan melawan hukum yang dilakukan Notaris dapat dituntut ganti kerugian sebagaimana dimaksud dalam Pasal 84 Undang-Undang Jabatan Notaris.

Pasal 12 huruf a Undang-Undang Jabatan Notaris ini juga bertentangan dengan asas dalam kelangsungan usaha dalam Undang-Undang Kepailitan. Asas ini bertujuan untuk memberikan peluang atau kemungkinan bagi usaha debitur untuk tetap dilangsungkan. Notaris yang mengalami kepailitan seharusnya tetap dapat bisa menjalankan jabatannya sebagai Notaris. Notaris sebagai pejabat umum yang bertugas dan berkewajiban untuk membuat akta otentik, dalam pembuatan akta otentik ini mendapatkan honorarium dari klien atau pihak yang menggunakan jasa dari Notaris tersebut. ${ }^{7}$

Notaris yang diberhentikan dengan tidak hormat dari jabatannya merupakan ranah hukum administrasi. Sanksi administratif menjadi salah satu pembahasan dalam Undang-Undang Jabatan Notaris dikarenakan sebagian kedudukan Notaris merupakan pejabat umum yang juga tunduk pada hukum administrasi. Penjatuhan sanksi administrasi berupa pemberhentian secara tidak hormat terhadap Notaris atas alasan penjatuhan pailit sangat bertentangan dengan prinsip dasar dan akibat dari hukum kepailitan yang diatur dalam Undang-Undang Kepailitan. Sebagaimana diatur dalam Pasal 21 sampai dengan Pasal 40 UndangUndang Kepailitan, kepailitan hanya meliputi penguasaan dan pengurusan terhadap harta kekayaan debitur pailit, dan bukan pada status jabatan seorang

${ }^{7}$ Putri Pertiwi Santoso, "Analisis Yuridis Terhadap Pengangkatan Kembali Notaris Yang Telah Dinyatakan Pailit Oleh Pengadilan”, Jurnal, Magister Kenotariatan Fakultas Hukum Universitas Brawijaya Malang, Malang, 2015. 
debitur. Undang-Undang Kepailitan telah mengatur secara jelas dan terperinci mengenai pihak-pihak yang dapat dinyatakan pailit, dan akibat-akibat hukum dari keputusan pailit, namun isi regulasi pada Undang-Undang Jabatan Notaris justru belum sepenuhnya mengacu pada Undang-Undang Kepailitan.

\section{Akibat Hukum Terhadap Notaris yang Dinyatakan Pailit}

1. Akibat Hukum Terhadap Notaris menurut Undang-Undang Nomor 37 Tahun 2004 tentang Kepailitan

Seorang Notaris sebagai debitur sepanjang telah memenuhi ketentuan

Pasal 2 ayat (1) Undang-Undang Kepailitan, maka Notaris dapat diajukan permohonan pernyataan pailit. Namun Notaris tersebut harus dipandang kapasitasnya sebagai orang pribadi karena hukum kepailitan merupakan Hukum Perdata yang bersifat khusus. Kekhususan itu terletak pada harta kekayaan yang menjadi objek gugatan, yaitu seluruh harta kekayaan menjadi objek gugatan tidak termasuk peralatan mata pencaharian.

Menurut Undang-Undang Kepailitan, konstruksi hukum kepailitan memberi peluang pengakhiran, meskipun putusan pailit telah berkekuatan hukum tetap. Akibat dari debitur yang dinyatakan pailit tersebut akan kehilangan hak untuk melakukan perbuatan hukum atas harta kekayaannya akan tetapi tidak berarti debitur tidak boleh untuk melakukan perbuatan hukum lainnya seperti hak untuk bekerja atau menjalankan profesi, karena hal tersebut akan menambah harta pailit debitur.

Notaris yang dinyatakan pailit oleh Pengadilan Niaga akan kehilangan kecakapan untuk mengurus harta kekayaannya. Semua harta kekayaan Notaris sebagai debitur itu dapat berupa benda bergerak maupun tidak bergerak, baik berwujud maupun tidak berwujud, baik yang telah ada pada saat pernyataan pailit diucapkan maupun yang akan ada di kemudian hari selama kepailitan itu berlangsung, dengan pengecualian. Undang-Undang Kepailitan mengecualikan beberapa hal yang tidak termasuk dalam harta pailit (Pasal 22 Undang-Undang Kepailitan), yaitu:

1) Benda, termasuk hewan yang benar-benar dibutuhkan oleh debitur sehubungan dengan pekerjaannya, perlengkapannya, alat-alat medis yang dipergunakan untuk kesehatan, tempat tidur dan perlengkapannya yang 
dipergunakan oleh debitur dan keluarganya, dan bahan makanan untuk 30 hari bagi debitur dan keluarganya, yang terdapat di tempat itu.

2) Segala sesuatu yang diperloeh oleh debitur dari pekerjaannya sendiri sebagai penggajian atau dari suatu jabatan atau jasa, sebagai upah, pensiun, uang tunggu atau uang tunjangan, sejauh yang ditentukan oleh hakim pengawas.

3) Uang yang diberikan kepada debitur untuk memenuhi suatu kewajiban memberi nafkah menurut undang-undang. ${ }^{8}$

Pasal 22 huruf a mengatur bahwa benda, termasuk hewan yang benar-benar dibutuhkan oleh debitur sehubungan dengan pekerjaannya, perlengkapannya, alat-alat medis yang dipergunakan untuk kesehatan, tempat tidur dan perlengkapannya yang dipergunakan oleh debitur dan keluarganya itu tidak boleh disita. Misalnya seseorang yang berprofesi sebagai dokter yang telah dinyatakan pailit, maka alat-alat medis yang dimiliki oleh dokter tersebut tidak boleh disita, karena bukan termasuk dalam objek kepailitan. Dengan tidak disitanya alat-alat medis tersebut, maka dokter tetap dapat menjalankan tugasnya sebagai dokter. Begitu pula dengan seorang Notaris, segala perlengkapan dan inventaris kantor milik Notaris tidak dapat disita dan masih dapat dipergunakan untuk menjalankan profesinya. Namun dalam Undang-Undang Jabatan Notaris, hal tersebut tidak diatur lebih lanjut, sehingga sangat merugikan profesi Notaris karena bagaimanapun Notaris disini kedudukannya sebagai subjek hukum yang masih mempunyai kewenangan terhadap hak-hak keperdataannya.

Pasal 22 huruf b Undang-Undang Kepailitan menentukan bahwa segala sesuatu yang diperoleh Notaris sebagai debitur pailit yang berasal dari penggajian atau upah yang didapat dari jabatan yang dijalaninya tidak dapat dimasukkan ke dalam objek pailit. Dengan demikian, apabila terdapat pihak yang mengaitkan antara kepailitan dengan hal-hal diluar harta kekayaan debitur pailit tidaklah tepat dan kurang pas. Kepailitan bukan suatu tindakan kriminal yang menjadikan debitur pailit tidak cakap dan tidak berwenang terhadap segala hal. Debitur yang berprofesi sebagai Notaris yang dinyatakan pailit hanya tidak cakap dalam mengurus harta kekayaannya saja sehingga hak-hak lain dari debitur tetap cakap dalam melakukan perbuatan hukum yang lain. Hak-hak lain

8 Pasal 22 Undang-Undang Nomor 37 Tahun 2004 tentang Kepailitan dan Penundaan Kewajiban Pembayaran Utang. 
disini adalah Notaris yang telah dinyatakan pailit berhak dan cakap untuk menjalankan kewenangannya sebagai pejabat.

Namun, apabila Notaris mendapat penghasilan ataupun upah maka tidak boleh masuk ke dalam rekening milik Notaris, penghasilan tersebut akan masuk ke dalam rekening milik kurator yang dibuat untuk mewakili Notaris, untuk memudahkan kurator mengurus dan mengawasi harta kekayaan milik Notaris. Dengan adanya penghasilan yang diperoleh Notaris, maka dapat menambah harta pailit Notaris, sehingga dapat memudahkan Notaris untuk membayar utang-utangnya kepada para kreditur. Oleh karena itu, ketika Notaris dinyatakan pailit, kemudian ia tidak boleh melakukan profesi jabatannya itu sangat tidak sesuai dengan ketentuan Undang-Undang Kepailitan, hal ini bertentangan dengan asas keadilan bagi Notaris.

Apabila Notaris diberhentikan dari profesinya secara tidak hormat maka ia tidak akan mendapat honorarium atau penghasilan untuk bisa menambah harta pailit miliknya. Tidak hanya itu disaat Notaris diberhentikan secara tidak hormat maka Notaris tidak dapat diangkat kembali untuk menjadi Notaris, karena dalam Undang-Undang Jabatan Notaris tidak terdapat aturan secara khusus tentang pengangkatan kembali Notaris yang telah dinyatakan pailit. Sedangkan di dalam Undang-Undang Kepailitan diatur tentang mengenai rehabilitasi kepailitan, agar debitur pailit dapat memulihkan nama baiknya kembali melalui putusan Pengadilan yang berisi keterangan bahwa debitur telah memenuhi kewajibannya.

Notaris dalam keadaan pailit harus menjalankan tugas dan jabatannya sesuai dengan kapasitasnya dan harus menguntungkan harta pailit, seperti tidak menghambur-hamburkan inventaris kantor dan Notaris dapat membuat perikatan dengan klien yang bisa menguntungkan harta pailit.

Pada prinsipnya setiap orang sepanjang tidak ditentukan lain oleh undangundang dianggap cakap atau mampu melakukan tindakan hukum, yang dalam konteks ini untuk membuat perjanjian sehingga menimbulkan perikatan. Orang yang oleh undang-undang dinyatakan tidak cakap, dilarang melakukan tindakan hukum termasuk membuat perjanjian. Pasal 1320 menyebutkan syarat 
kedua untuk sahnya perjanjian yaitu adanya kecakapan untuk membuat perikatan (om eene verbintenis aan te gaan). ${ }^{9}$ Selanjutnya Pasal 1329 mengatur bahwa "setiap orang adalah wenang" (bevoegd) untuk membuat perikatan, jika ia oleh undang-undang tidak dinyatakan tidak cakap. ${ }^{10}$ Orang yang dinyatakan tidak wenang adalah orang yang secara umum cakap untuk bertindak, tetapi untuk hal-hal tertentu "tidak". Orang yang tidak cakap untuk bertindak pasti orang yang tak wenang, sedang orang yang tak wenang adalah orang yang pada umumnya cakap untuk bertindak, tetapi pada peristiwa tertentu tidak dapat melaksanakan tindakan hukum, dalam hubungannya dengan konteks ini adalah tidak wenang menutup perjanjian tertentu (secara sah). ${ }^{11}$

Pasal 1330 juga mengatur bahwa yang tidak cakap untuk membuat perjanjian adalah para curandi, orang-orang yang ditaruh di bawah curatele/pengampuan. Undang-undang berangkat dari anggapan bahwa semua orang yang terganggu jiwanya, lemah akalnya dan pemboros berada di bawah pengampuan (atau paling tidak suatu ketika akan berada di bawah pengampuan). ${ }^{12}$ Pengampuan adalah keadaan dimana seseorang karena sifat pribadinya dianggap tidak cakap di dalam lalu lintas hukum, karena dianggap tidak cakap maka guna menjamin hak-haknya, hukum memperkenankan seseorang untuk dapat bertindak sebagai wakil dari orang yang dibawah pengampuan tersebut.

Merujuk Pasal 433 KUHPerdata, salah satu alasan pengampuan adalah keborosan, maka pengampuan dalam konstruksi hukum perdata berbeda dengan pengampuan dalam kepailitan. Pada proses kepailitan pengampuan bertujuan untuk menjamin adanya suatu proses pemenuhan kewajiban dan pembagian harta kekayaan debitur pailit kepada para krediturnya. Debitur pailit sudah kehilangan hak untuk mengurus hartanya sebagaimana telah diatur dalam Pasal 24 ayat (1) Undang-Undang Kepailitan, yang segala pengurusan dan pemberesan harta debitur pailit dilakukan oleh kurator sebagai pengampu.

Debitur kehilangan hak untuk mengurus hartanya akibat adanya kepailitan yang dialaminya. Sehingga para kreditur akan mengalami

\footnotetext{
9 J.Satrio, Hukum Perikatan, Perikatan Yang Lahir Dari Perjanjian, Citra Aditya Bakti, Bandung, 1995, hlm. 1.

${ }_{10}$ Ibid., hlm. 2.

11 Ibid., hlm. 3.

12 J.Satrio, Hukum Perjanjian, Citra Aditya Bakti, Bandung, 1992, hlm. 282
} 
ketidakpastian antara hubungan hukum yang antara kreditur dan debitur pailit. Oleh karena itu segala pengurusan administratif dan likuidasi harta pailit dilakukan oleh kurator. Kewenangan kurator tersebut diatur dalam Pasal 16 Undang-Undang Kepailitan. "Kurator berwenang melaksanakan tugas pengurusan dan/atau pemberesan atas harta pailit sejak tanggal putusan pailit diucapkan meskipun terhadap putusan tersebut diajukan kasasi atau peninjauan kembali". ${ }^{13}$

Undang-Undang Jabatan Notaris belum banyak mengatur mengenai kepailitan Notaris seperti yang telah disebutkan di atas. Undang-Undang Jabatan Notaris hanya mengatur perihal pemberhentian Notaris secara tidak hormat saja, dan hal-hal lain terkait dengan kepailitan belum diatur dalam undang-undang tersebut. Seperti pengaturan dokumen-dokumen resmi milik Notaris, apakah akan diamankan oleh kurator atau diamankan oleh organisasi Notaris itu sendiri. Mengingat bahwa segala dokumen resmi milik Notaris merupakan suatu kerahasiaan antara Notaris dengan klien. Sehingga apabila Notaris mengalami pailit, mekanisme pengurusannya masih belum jelas, bahkan setelah pemberhentian Notaris tidak ada pengaturan mengenai apakah Notaris dapat diangkat kembali ataukah tidak setelah ia memenuhi kewajibannya sebagai debitur pailit. Oleh karena itu terjadi kekaburan norma karena tidak adanya pengaturan yang spesifik terkait kepailitan Notaris dalam Undang-Undang Jabatan Notaris dan hal tersebut menyebabkan banyak penafsiran yang berbeda-beda tentang kepailitan Notaris.

Namun jika merujuk Pasal 98 Undang-Undang Kepailitan, segala suratsurat dan dokumen-dokumen resmi milik Notaris akan diamankan oleh kurator, berdasarkan tugas dan wewenang kurator. Pada dasarnya kurator wajib bertindak transparan di hadapan para pihak yang terlibat dalam penguasaannya. Kurator juga wajib memberikan informasi material secara seimbang kepada para pihak yang terlibat dalam kepailitan tersebut. Terlepas

13 Pasal 16 Undang-Undang Nomor 37 Tahun 2004 tentang Kepailitan dan Penundaan Kewajiban Pembayaran Utang 
dari kewajiban transparansi tersebut pada beberapa masalah tertentu yang tidak disebut oleh undang-undang maka kurator wajib merahasiakan hal-hal yang berkaitan dengan penguasaannya. Kurator tidak diperbolehkan menunjukkan dan/atau menyampaikan kepada pihak ketiga manapun tentang informasi yang bersifat rahasia yang diperoleh dalam pelaksanaan tugasnya sebagai kurator atau pengurus. Kurator dilarang menggunakan informasi tersebut untuk keperluan apapun, kecuali untuk menjalankan tugasnya dalam rangka kepailitan atau penundaan kewajiban pembayaran utang. Sehingga menurut penulis peraturan tentang dokumen rahasia milik Notaris tetap mengacu pada Undang-Undang Kepailitan yang berada dibawah penguasaan kurator. Kewajiban menjaga kerahasiaan ini dapat dikecualikan dalam hal informasi tersebut :

a. Merupakan atau telah menjadi informasi yang tersedia bagi publik yang bukan akibat dari pelanggaran atas ketentuan kerahasiaan ini;

b. Diterima dari pihak ketiga yang tidak terikat kewajiban kerahasiaan atas informasi tersebut;

c. Berdasarkan hukum atau untuk keputusan pengadilan dan/atau badan arbitase yang berwenang, mengharuskan Kurator atau pengurus untuk memberikan informasi tersebut; atau

d. Dokumen dan informasi yang wajib diberikan Kurator dan pengurus, dokumen dan informasi mana berdasarkan undang-undang dinyatakan terbuka untuk umum. ${ }^{14}$

Menurut Pasal 100 ayat (1) Undang-Undang Kepailitan, kurator harus secepatnya mulai membuat pencatatan mengenai harta pailit. Hal itu harus dilakukan dua hari setelah kurator menerima surat putusan pengangkatan sebagai kurator. Pencatatan harta pailit tersebut, menurut Pasal 100 ayat (2) Undang-Undang Kepailitan dapat dilakukan di bawah tangan sepajang disetujui oleh hakim pengawas. Artinya, tidak perlu harus dilakukan dengan akta otentik. Untuk validitas pencatatan tersebut, Pasal 100 ayat (3) menentukan anggota panitia kreditur sementara berhak menghadiri pembuatan pencatatan tersebut. ${ }^{15}$

\footnotetext{
14 Junita Sari Ujung, "Independensi Kurator Dalam Pengurusan dan Pemberesan Harta Pailit”, Jurnal, Magister Kenotariatan Fakultas Hukum Universitas Indonesia Depok, Depok, 2008.

${ }^{15}$ Sutan Remy Sjahdeini, Hukum Kepailitan: Memahami..., Op.Cit., hlm. 214
} 
Ketika semua kewajiban debitur telah terpenuhi, dan segala piutang kreditur telah dibayarkan dengan jumlah penuh maka berakhirlah kepailitan yang terjadi pada debitur. Oleh karena itu, Pasal 215 Undang-Undang Kepailitan mengatur bahwa setelah berakhirnya kepailitan, baik karena perdamaian, pembayaran utang kepada kreditur atau daftar pembagian penutup menjadi mengikat, ataupun berakhirnya kepailitan dari harta kekayaan debitur yang meninggal dunia, maka debitur atau ahli waris diperbolehkan mengajukan rehabilitasi kepada Pengadilan. Rehabilitasi adalah pemulihan nama baik debitur yang semula dinyatakan pailit, melalui putusan pengadilan yang berisi keterangan bahwa debitur telah memenuhi kewajibannya.

2. Dampak terhadap Akta yang dibuat oleh Notaris menurut Undang-Undang Nomor 2 Tahun 2014 tentang Jabatan Notaris

\section{a. Akta Kehilangan Otentisitasnya}

Pasal 84 Undang-Undang Jabatan Notaris menyatakan bahwa suatu akta yang dibuat oleh seorang Notaris akan menjadi hilang ontentisitasnya apabila dalam pembuatan akta tersebut Notaris melakukan pelanggaran terhadap Pasal 16 ayat (1) huruf i, Pasal 16 ayat (1) huruf k, Pasal 42 atau Pasal 52. Sebab, akta yang dibuat oleh Notaris tersebut menjadi akta dibawah tangan dan Notaris wajib untuk memberikan ganti rugi biaya pembuatan akta, serta wajib memberikan ganti rugi kepada pihak yang dirugikan.

Apabila Notaris digugat oleh para pihak atau penghadap dan gugatan tersebut telah terbukti dan memiliki putusan pengadilan yang berkekuatan hukum tetap maka akta Notaris akan terdegradasi kedudukannya dari akta otentik menjadi akta dibawah tangan. Kekuatan pembuktian akta dibawah tangan itu digunakan untuk membenarkan (mengakui) atau memungkiri tandatangannya. Dalam hal tandatangan dipungkiri, maka hakim harus memerintahkan agar kebenaran akta itu diperiksa. Baru kalau tandatangan diakui oleh yang bersangkutan, maka akta dibawah tangan itu mempunyai kekuatan dan menjadi bukti sempurna. ${ }^{16}$ Nilai pembuktian akta dibawah tangan tergantung pada para pihak dan hakim yang menilainya.

${ }^{16}$ Sudikno Mertokusumo, Hukum Acara Perdata Indonesia, Liberty, Yogyakarta, 1993, hlm. 131 
Jika pendegradasian kedudukan akta tersebut ternyata merugikan pihak yang bersangkutan dan dapat dibuktikan oleh pengugat, maka penggugat dapat menuntut ganti rugi kepada Notaris yang bersangkutan. Apabila Notaris tidak dapat membayar ganti rugi yang dituntut oleh penggugat berdasarkan putusan pengadilan yang telah mempunyai kekuatan hukum tetap dikarenakan harta kekayaan milik Notaris tidak cukup untuk membayar ganti rugi tersebut maka hal ini bisa dijadikan dasar untuk menjadikan Notaris pailit.

\section{b. Batal demi Hukum dan dapat dibatalkan}

Pasal 84 Undang-Undang Jabatan Notaris menegaskan bahwa jika seorang Notaris melakukan pelanggaran dalam pembuatan akta, karena ada unsur perbuatan melawan hukum dan wanprestasi, maka akta yang dibuat oleh Notaris tersebut akan menjadi batal demi hukum. Hal ini juga dapat dijadikan alasan para pihak yang merasa dirugikan dalam menggunakan jasa Notaris dalam pembuatan akta tersebut untuk menuntut biaya, ganti rugi dan bunga kepada Notaris.

\section{Penutup}

Penelitian ini menyimpulkan adanya kontradiksi peraturan yang berbeda antara Undang-Undang Jabatan Notaris dan Undang-Undang Kepailitan. UndangUndang Kepailitan memang tidak secara khusus mengatur mengenai jabatan Notaris tetapi dapat diinterpretasikan bahwa kepailitan yang diatur dalam Undang-Undang Jabatan Notaris sebatas tidak cakap hukum dan tidak berwenang bertindak dalam harta kekayaannya saja. Sehingga pemberhentian Notaris secara tidak hormat dianggap mengabaikan asas keadilan bagi Notaris, karena pada prinsipnya kepailitan hanya bersifat sementara atau dapat diakhiri dan hanya berkaitan dengan harta kekayaan debitur secara pribadi saja.

Akibat hukum dari Notaris In Pailit berdasarkan Undang-Undang Kepailitan hanya menyebabkan seorang kehilangan hak untuk berbuat bebas terhadap harta kekayaannya saja, tetapi tidak kehilangan hak untuk menjalankan profesi dan jabatannya. Pasal 22 Undang-Undang Kepailitan mengatur pengecualian harta pailit, bahwa segala sesuatu yang berhubungan dengan pekerjaannya tidak dapat 
disita, termasuk hasil dari penggajian atau upah yang diterima oleh Notaris tidak dapat dimasukkan ke dalam objek pailit. Notaris tetap dapat menjalankan profesinya sepanjang dapat menguntungkan harta pailit namun tetap dibawah pengawasan kurator. Kurator juga akan mengamankan segala dokumen resmi dan rahasia milik Notaris sesuai dengan Pasal 98 Undang-Undang Kepailitan. Menurut Undang-Undang Jabatan Notaris, kepailitan yang terjadi pada Notaris menyebabkan berubahnya status hukum dari Notaris menjadi tidak cakap dalam melakukan perbuatan hukum, sehingga menyebabkan akta yang dibuat oleh Notaris setelah diputus pailit yang berkekuatan hukum tetap oleh Pengadilan akan menjadi akta dibawah tangan.

Pemerintah perlu melakukan kajian ulang secara mendasar dan menyeluruh terhadap pengaturan kepailitan bagi Notaris sebagaimana dimaksud dalam Pasal 12 huruf a Undang-Undang Jabatan Notaris agar tidak terjadi kekaburan dan benturan norma dengan Undang-undang Kepailitan. Perlu adanya penambahan pasal dalam Undang-Undang Jabatan Notaris untuk mengatur kepailitan yang dialami oleh Notaris, sehingga terdapat kejelasan tentang kepailitan Notaris secara menyeluruh. Pengaturannya tidak hanya pada pemberhentian secara tidak hormat saja, namun juga menjangkau aspek lain yang mengatur tentang kepailitan, dengan melihat regulasi pada Undang-Undang Kepailitan.

\section{Daftar Pustaka}

\section{Buku}

Adjie, Habib, Sanksi Perdata dan Administrasi Terhadap Notaris Sebagai Pejabat Publik, Refika Aditama, Bandung, 2008.

J. Satrio, Hukum Perikatan, Perikatan Yang Lahir Dari Perjanjian, Citra Aditya Bakti, Bandung, 1995.

J.Satrio, Hukum Perjanjian, Citra Aditya Bakti, Bandung, 1992.

Kansil, C.S.T. dan Christine S.T.Kansil, Pokok-Pokok Etika Profesi Hukum, Pradnya Paramita, Jakarta, 1997.

Kie, Tan Thong, Studi Notariat Beberapa Mata Pelajaran Dan Serba Serbi Praktek Notaris, PT. Ichtiar Baru Van Hoeve, Jakarta, 1994.

Mertokusumo, Sudikno, Hukum Acara Perdata Indonesia, Liberty, Yogyakarta, 1993. 
Rosjidi Ranggawidjaya, Pengantar Ilmu Perundang-Undangan Indonesia, Mandar Maju, Bandung, 1998.

Shubhan, Hadi, Hukum Kepailitan, Prinsip, Norma, dan Praktik di Peradilan, Kencana Prenada Media Group, Jakarta, 2008.

Sjahdeini, Sutan Remy, Hukum Kepailitan: Memahami Undang-Undang Kepailitan No.37 Tahun 2004 Tentang Kepailitan, PT Pustaka Utama Grafiti, Jakarta, 2002.

\section{Jurnal}

Putri Pertiwi Santoso, "Analisis Yuridis Terhadap Pengangkatan Kembali Notaris Yang Telah Dinyatakan Pailit Oleh Pengadilan", Jurnal, Magister Kenotariatan Fakultas Hukum Universitas Brawijaya Malang, Malang, 2015.

Junita Sari Ujung, “Independensi Kurator Dalam Pengurusan dan Pemberesan Harta Pailit", Magister Kenotariatan Fakultas Hukum Universitas Indonesia Depok, Jurnal, Depok, 2008.

\section{Peraturan Perundang-Undangan}

Kitab Undang-Undang Hukum Perdata

Undang-Undang Nomor 37 tahun 2004 tentang Kepailitan dan Penundaan Kewajiban Pembayaran Utang.

Kode Etik Notaris Ikatan Notaris Indonesia (I.N.I) Undang-Undang Nomor 2 Tahun 2014 tentang Jabatan Notaris 